\title{
Evaluation of five protocols for DNA extraction from leaves of Malus sieversii, Vitis vinifera, and Armeniaca vulgaris
}

\author{
K. Aubakirova ${ }^{1,2}$, M. Omasheva ${ }^{1}$, N. Ryabushkina ${ }^{1}$, T. Tazhibaev ${ }^{2}$, \\ G. Kampitova ${ }^{2}$ and N. Galiakparov ${ }^{1}$ \\ ${ }^{1}$ Institute of Plant Biology and Biotechnology, Almaty, Kazakhstan \\ ${ }^{2}$ Kazakh National Agrarian University, Almaty, Kazakhstan \\ Corresponding author: K. Aubakirova \\ E-mail: karla_78@mail.ru
}

Genet. Mol. Res. 13 (1): 1278-1287 (2014)

Received January 31, 2013

Accepted July 26, 2013

Published February 27, 2014

DOI http://dx.doi.org/10.4238/2014.February.27.13

\begin{abstract}
Leaves of Malus sieversii, Vitis vinifera, and Armeniaca vulgaris contain substantial amounts of secondary metabolites, which limit the high-quality DNA extraction performance. In this study, five extraction protocols were compared for their ability to produce good quality DNA from fresh and dried (with silica gel) leaves of these species. The modified protocol of Dellaporta et al., using polyvinylpyrrolidone to bind the phenolic compounds and a high molar concentration of potassium acetate to inhibit co-precipitation of polysaccharides with DNA, produced the best DNA quality for all species tested. DNA extracted by this method had a 1.77-1.96 $\mathrm{A}_{260 / 280} \mathrm{~nm}$ ratio and successful amplification of the $18 \mathrm{~S}$ ribosomal DNA gene. DNA concentrations of dried leaves were lower than those obtained from fresh leaves, which was likely due to aspects of the drying procedure. All five methods for grapevine produced DNA of obvious better quality from green canes compared to leaves, due to the relatively low content of secondary metabolites in the former. For grapevine and apricot, three methods can be equally used to obtain DNA of good quality: the Doyle and Doyle modified method using CTAB
\end{abstract}


and high concentration of $\mathrm{NaCl}$, the Jobes et al. modified method, and the sodium dodecyl sulfate mini preparation method of Edwards et al. The protocol of Jobes et al. using $\mathrm{LiCl}$ for RNA removal showed the best results for most of the $M$. sieversii samples examined.

Key words: Malus sieversii; Vitis vinifera; Armeniaca vulgaris; DNA extraction; Polymerase chain reaction

\section{INTRODUCTION}

In Kazakhstan, horticulture and viticulture have been recently rejuvenated as important branches of agriculture. Kazakhstan's biodiversity of cultivated representatives of apple (Malus domestica Borkh.), apricot [Prunus armeniaca L. (syn. Armeniaca vulgaris Lam.)], and grapevine (Vitis vinifera L.) has recently been evaluated by horticulturists [International Biodiversity Project/UNEP-GEF "In situ/On Farm Preservation and the Use of Agrobiodiversity (fruit cultivars and wild fruit species) in Central Asia" (Component of Kazakhstan), 2006-2011]. On the other hand, wild representatives of apple, apricot, and grapevine may harbor traits with varying levels of resistance to biotic and abiotic stress factors. Wild apple Malus sieversii (Ledeb.) M. Roem has been identified, based on a phylogenetic reconstruction of the Pyreae and Malus genus, as the main progenitor of the cultivated apple (Velasco et al., 2010). The Tian Shan forests were identified as the geographic area from where the apple was first domesticated (Vavilov, 1926). According to the FFI/IUCN SSC Central Asian regional tree Red Listing workshop, Bishkek, Kyrgyzstan (11-13 July 2006), M. sieversii is declining at a rapid rate. For example, in Kazakhstan, its habitat has declined by over $70 \%$ in the last 30 years. This species is listed as "vulnerable" in the IUCN Red List of Threatened Species. $P$. armeniaca L. originates from Central Asia. The wild apricot is considered to be very rare in all countries where it naturally occurs. In Kazakhstan, it is only known in three localities in Zaylyisky Alatay. Its distribution is severely fragmented, and there are continuing declines in the area. Consequently, it is classified as "endangered" in the IUCN Red List of Threatened Species (IUCN, 2012). In the Tian-Shan mountains, there are rare and small locations of wild $V$. vinifera representatives. All of the above indicates an urgent need to evaluate the existing biodiversity of wild and cultivated representatives of these species using molecular genetic approaches in order to manage these species' germplasm well, and for the development of genetic selection programs related to adaptive traits.

Studies based on DNA markers require good quality genomic DNA, emphasizing the need for inexpensive, rapid, and simple DNA extraction methods (Ausubel et al., 2002). At present, there are several different commercially available DNA isolation kits; however, their high cost per sample restricts exhaustive analyses. Furthermore, the DNA quantity and quality often vary among representatives of different genera, and sometimes even among different species of a genus or among different plant tissues. The presence of some cellular components in extracted DNA samples can inhibit downstream molecular reactions (Bushra et al., 1999). Limitations conditioned by genetic materials may be solved by some changes in the composition and $\mathrm{pH}$ of functional buffers, which enables the quantification and qualification of extracted DNA (Lodhi et al., 1994). Therefore, for efficient analyses of several types of samples, it is important to use methods that do not necessarily involve high-cost laboratory equipment, 
which can produce good quality results.

All methods currently available for DNA isolation accomplish the following: cell membrane disruption (using detergents) so that the DNA is released into the extraction buffer, protection of DNA from endonucleases with chelating agents, and separation of DNA from proteins, polyphenols, polysaccharides, and RNA. To obtain good quality DNA, the utilization of fresh young leaf tissue is ideal due to its relatively lower concentration of polysaccharides, polyphenols, and other secondary metabolites (Sytsma et al., 1993). However, different and distant locations of wild species do not always allow for such samples to be obtained. In such cases, the material is generally stored (dried) in silica gel, which unfortunately results in lower yield and quality of DNA (Akinnagbe et al., 2012). Failure to amplify DNA from particular plant species is a persistent problem, even when the template DNA is extracted from fresh tissue and spectrophotometric analysis indicates high DNA yield and quality (Samarakoon et al., 2013).

In this study, we compared five different DNA isolation protocols for their ability to produce good quality DNA in order to find an appropriate method that enables the extraction of high quality DNA from fresh and dried material of M. sieversii, V. vinifera, and A. vulgaris that would be suitable for polymerase chain reactions (PCRs).

\section{MATERIAL AND METHODS}

\section{Plant material}

Fresh leaves of M. sieversii were collected from a native population in Tauturgen, in the southern Kazakhstan region. Leaves and green canes of the $V$. vinifera cultivar Riesling were collected from the Institute of Plant Biology and Biotechnology's experimental plot, and the leaves of $A$. vulgaris were obtained from trees cultivated on a private plot. All collected samples of fresh leaves and canes were ground immediately for DNA isolation or stored in a freezer at $-80^{\circ} \mathrm{C}$. Another part of the fresh leaves of each sample from all species was dried with $1 \mathrm{~g}$ silica gel per $100 \mathrm{mg}$ fresh weight for $24 \mathrm{~h}$. The DNA yield was calculated based on the plant material's dry weight.

\section{Testing DNA extraction protocols}

All DNA extraction protocols were analyzed in three groups of samples: 1) fresh leaves, green canes, and dried leaves of $V$. vinifera, 2) fresh leaves and dried leaves of $M$. sieversii, and 3 ) fresh leaves and dried leaves of $A$. vulgaris. In all protocols, $100 \mathrm{mg}$ fresh leaf tissue (corresponding to $20 \mathrm{mg}$ dry weight) and $20 \mathrm{mg}$ dried samples were utilized from each sample, and ground in liquid nitrogen immediately prior to the procedures. The equipment and materials used in all protocols were mortar and pestle, 1.5 and $2.0-\mathrm{mL}$ microcentrifuge tubes, liquid nitrogen, water bath, centrifuge and rotor capable of $16,100 \mathrm{~g}$, and 2-mL holding tubes. All centrifugation steps in protocols B, C, and D (see below) were performed at 16,100 $\mathrm{g}$ for $15 \mathrm{~min}$.

The last step in each method was re-precipitation of DNA with ethanol after incubation with $10 \mathrm{mg} / \mathrm{mL}$ RNAse $\mathrm{A}$ in order to eliminate reaction products that could inhibit further processes (PCR). Equal volumes of ice-cold absolute ethanol were added to each sample before centrifugation at $16,100 \mathrm{~g}$ for $10 \mathrm{~min}$. The supernatant was discarded and the DNA pellet was dried and suspended in $50 \mu \mathrm{L}$ double distilled water. 
DNA extraction protocol A (slightly modified protocol developed by Edwards et al., 1991)

A 100-mg leaf sample powder obtained in liquid nitrogen was thawed and suspended in $1 \mathrm{~mL}$ extraction buffer containing $200 \mathrm{mM}$ Tris- $\mathrm{HCl}$, pH 7.5, $25 \mathrm{mM}$ EDTA, $250 \mathrm{mM} \mathrm{NaCl}$, $10 \%$ sodium dodecyl sulfate (SDS), 10-20 mg polyvinylpyrrolidone (PVP), and $6.5 \mathrm{mM}$ dithiothreitol (DTT). The solution was centrifuged at $15,000 \mathrm{~g}$ for $2 \mathrm{~min}$. The supernatant was extracted with an equal volume of chilled chloroform, followed by centrifugation at $15,000 \mathrm{~g}$ for 10 min. Nucleic acids were precipitated with 0.6 volume cold isopropanol and centrifuged at 15,000 $g$ for $5 \mathrm{~min}$. The pellet was washed with $500 \mu \mathrm{L} \mathrm{70 \%}$ ethanol, air dried, resuspended in $100 \mu \mathrm{L}$ water, and incubated overnight at $55^{\circ} \mathrm{C}$. A second round of chloroform extraction was then performed. $\mathrm{NaCl}$ was added to the aqueous phase up to a $0.6 \mathrm{M}$ final concentration, and centrifuged for $15 \mathrm{~min}$ at $15,000 \mathrm{~g}$. The supernatant was used for DNA precipitation with isopropanol after washing with $70 \%$ ethanol dissolved in $50 \mu \mathrm{L}$ water and treatd with RNase A.

\section{DNA extraction protocol B (modified from Jobes et al., 1995)}

A 100-mg leaf sample was suspended in $1 \mathrm{~mL}$ extraction buffer $(100 \mathrm{mM}$ sodium acetate, $100 \mathrm{mM}$ EDTA, $500 \mathrm{mM} \mathrm{NaCl}, 10 \mathrm{mM}$ DTT, 2\% PVP (w/v), $\mathrm{pH} 5.5$, and proteinase $\mathrm{K}$ to a final concentration of $100 \mu \mathrm{g} / \mathrm{mL}$ ), followed by incubation for $1 \mathrm{~h}$ at $55^{\circ} \mathrm{C}$ with occasional swirling. SDS was added to a final concentration of $1.5 \%$, and the sample was incubated for an additional $1 \mathrm{~h}$ at $55^{\circ} \mathrm{C}$. Following centrifugation, the supernatant was mixed with $1 / 3$ volume $5 \mathrm{M}$ sodium acetate, incubated at $-20^{\circ} \mathrm{C}$ for $30 \mathrm{~min}$, and centrifuged once more. DNA was precipitated with the addition of 0.6 volume isopropanol, and was incubated overnight at $-20^{\circ} \mathrm{C}$. Following centrifugation, DNA was dissolved in water and reprecipitated with 2 volumes ethanol in the presence of 0.5 volume $5 \mathrm{M} \mathrm{NaCl}$. DNA was dissolved in water, and any contaminating RNA was precipitated by the addition $1 / 3$ volume ice-cold $8 \mathrm{M} \mathrm{LiCl}$. The solution was incubated at $-20^{\circ} \mathrm{C}$ for $1 \mathrm{~h}$, and then centrifuged. The supernatant was precipitated with isopropanol and dissolved in $50 \mu \mathrm{L}$ water. Residual RNA was treated with RNase A.

\section{DNA extraction protocol C (modified from Dellaporta et al., 1983)}

One milliliter extraction buffer (10\% SDS, $50 \mathrm{mM}$ Tris- $\mathrm{HCl}, 100 \mathrm{mM} \mathrm{NaCl}, 10 \mathrm{mM}$ EDTA, pH 8.0, with the addition of $20 \mu \mathrm{L} / \mathrm{mL} \beta$-mercaptoethanol, and $10 \mathrm{mg}$ PVP) was added to 100 -mg leaf samples and the solution was incubated for $45 \mathrm{~min}$ at $65^{\circ} \mathrm{C}$. Sodium acetate was added to a final concentration of $1 \mathrm{M}$, and the sample was incubated for $20 \mathrm{~min}$ on ice. After centrifugation, DNA was precipitated from the supernatant by adding an equal volume isopropanol, and incubating for $1 \mathrm{~h}$ at $-20^{\circ} \mathrm{C}$. After another round of centrifugation, the pellet was washed with $70 \%$ ethanol and air-dried. DNA was dissolved in $100 \mu \mathrm{L}$ water, treated with RNase A, and then reprecipitated overnight with absolute ethanol in the presence of $0.3 \mathrm{M}$ sodium acetate. The next day, the pellet was washed with $70 \%$ ethanol, and DNA was dissolved in $50 \mu \mathrm{L}$ water.

\section{DNA extraction protocol D (modified from Doyle and Doyle, 1990)}

One hundred-milligram leaf sample was suspended in $1 \mathrm{~mL}$ extraction buffer $(2 \%$ cetrimonium bromide (CTAB), 100 mM Tris-HCl, pH 7.5, 1.4 M NaCl, 20 mM EDTA, pH 8.0, 
with the addition of $20 \mu \mathrm{L} / \mathrm{mL} \beta$-mercaptoethanol and $20 \mathrm{mg}$ PVP immediately prior to use) and incubated for $1 \mathrm{~h}$ at $60^{\circ} \mathrm{C}$, followed by $\sim 600 \mu \mathrm{L}$ chloroform extraction and centrifugation. DNA was precipitated from the supernatant by adding an equal volume of isopropanol followed by overnight incubation at $-20^{\circ} \mathrm{C}$. After washing the pellet with $70 \%$ ethanol, the DNA was dissolved in water and treated with RNase A.

\section{DNA extraction protocol E (modified from Doyle and Doyle, 1990)}

One hundred-milligram leaf sample was mixed in $1 \mathrm{~mL}$ extraction buffer (the same as in protocol $\mathrm{D}$, except that the 2-mercaptoethanol concentration was reduced 10 -fold) and incubated for $20 \mathrm{~min}$ at $60^{\circ} \mathrm{C}$, followed by chloroform extraction. Half and double volumes of $5 \mathrm{M} \mathrm{NaCl}$ and absolute ethanol, respectively, were added to the water phase. Following incubation at $4^{\circ} \mathrm{C}$ for $15-20 \mathrm{~min}$, samples were centrifuged at $3600 \mathrm{~g}$ for $3 \mathrm{~min}$, and then the speed was increased up to $6000 \mathrm{~g}$, and centrifugation continued for additional $3 \mathrm{~min}$. The pellet was washed with $70 \%$ ethanol, air-dried, and dissolved in water, and then treated with RNase A.

\section{PCR and electrophoresis}

The DNA samples were assessed for successful PCR amplification of the 18S ribosomal DNA gene using the following primers: forward: 5'-GAGAAACGGCTACCACATCCAAGG-3'; reverse: 5'- CCATGCACCACCACCCATAGAATC-3'. The expected size of the product was $870 \mathrm{bp}$.

PCR was performed in total volumes of $25 \mu \mathrm{L}$ containing $0.2 \mathrm{mM}$ deoxyribonucleotide triphosphates, $0.2 \mu \mathrm{M}$ of each primer, $0.5 \mathrm{U}$ Taq DNA polymerase (Thermo Scientific), $2.5 \mathrm{mM} \mathrm{MgCl}$, and $40 \mathrm{ng}$ template DNA in $1 \mathrm{X}$ Taq buffer with $\left(\mathrm{NH}_{4}\right)_{2} \mathrm{SO}_{4}[750 \mathrm{mM}$ Tris$\mathrm{HCl}, \mathrm{pH} 8.8$, at $25^{\circ} \mathrm{C}, 200 \mathrm{mM}\left(\mathrm{NH}_{4}\right)_{2} \mathrm{SO}_{4}$, and $0.1 \%$ (v/v) Tween 20]. The amplification reaction consisted of $2 \mathrm{~min}$ initial denaturation at $94^{\circ} \mathrm{C}$ followed by 25 cycles of denaturation at $94^{\circ} \mathrm{C}$ for $30 \mathrm{~s}$, annealing at $67^{\circ} \mathrm{C}$ for $15 \mathrm{~s}$, and synthesis at $72^{\circ} \mathrm{C}$ for $15 \mathrm{~s}$. The final extension took place at $72^{\circ} \mathrm{C}$ for $10 \mathrm{~min}$.

\section{Visualization, DNA quantification, and purity measurement}

The presence and quality of DNA obtained by each protocol was determined by electrophoresis on $1.5 \%$ TAE agarose gel stained with ethidium bromide, and was visualized under UV light. Equal amounts of DNA (100 ng per well) were applied for gel electrophoresis in order to observe the purity of DNA samples. Electrophoresis was carried out under a steady voltage of $80 \mathrm{~V}$ for 1-1.5 h, and the results were documented using the Gel Documentation System (Bio-Rad, USA). The yield and quality of extracted DNAs was measured spectrophotometrically, using a SmartSpec Plus Spectrophotometer (Bio-Rad). The purity of DNAs was assessed based on the $\mathrm{A}_{260 / 280} \mathrm{~nm}$ absorbance ratio.

\section{RESULTS AND DISCUSSION}

DNA extracted from fresh leaves of $V$. vinifera with protocols B, C, and $\mathrm{E}$ all showed good DNA quality and low degradation. DNA samples extracted using protocol A were colored yellowish or dark, which was likely due to rapid oxidation of the extract. The DNA extracted 
from canes and dried leaves were of good quality in all five protocols (Figure 1). In the grapevine samples, all five methods produced better quality DNA from green canes compared to fresh leaves, which was perhaps due to the relatively low content of secondary metabolites and high levels of antioxidants in canes (Balik et al., 2008). However, in most protocols, the concentration of DNA extracted from canes was lower than that obtained from dried leaves (Table 1). Secondary metabolites stored in vacuoles (Kulkarni et al., 2001) are released along with genetic material by crushing the leaf sample with detergents such as SDS or CTAB during the extraction procedure (Loomis, 1974). Once released, polyphenols in particular are oxidized with the atmospheric oxygen to form tannins and melanins, which have a high affinity for nucleic acids. Thus, oxidized polyphenols covalently bind to DNA and co-precipitate with it after the addition of alcohol, resulting in a brown color and a highly viscous solution (Guillemaut and Maréchal-Drouard, 1992). Despite the presence of antioxidants such as PVP in the lysis buffer, native antioxidants play an important role in the prevention or reduction of the oxidative destruction of biological compounds such as lipids, proteins, and nucleic acids (Halliwell, 1990).

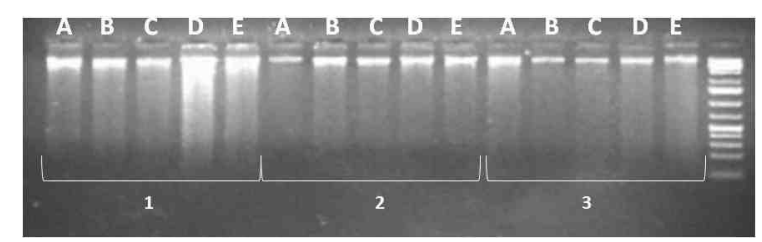

Figure 1. Electrophoresis of total DNA from Vitis vinifera extracted by protocols: A. modified Edwards et al. (1991); B. modified Jobes et al. (1995); C. modified Dellaporta et al. (1983); D. modified Doyle and Doyle (1990); E. modified Doyle and Doyle, 1990; lane 1 = fresh leaves; lane 2 = green canes; lane 3 = dried leaves; lane $M=$ GeneRuler ${ }^{\mathrm{TM}}$ 1-kb DNA Ladder Plus (Fermentas).

Protocol D (Doyle and Doyle, 1990) with fresh leaves showed poor results with respect to DNA quality $\left(\mathrm{A}_{260 / 280}=1.19\right)$ compared to dried leaves. A possible reason for this result may lie in the purification step, where the extract is treated with chloroform in order to remove proteins and lipids with consequent precipitation with isopropanol. On the other hand, in protocol E (modified from Doyle and Doyle, 1990), we used a high concentration of $\mathrm{NaCl}$, which facilitates the removal of polysaccharides by increasing their solubility in ethanol so that they do not co-precipitate with DNA (Fang et al., 1992). Protocol D was also inefficient for both the fresh and dried leaves of apple and apricot, as indicated by the absence of PCR products on the gel. In group 2, fresh leaves of $M$. sieversii exhibited better DNA concentration and quality than dried leaf samples for extraction protocol A, in which the buffer contained the SDS detergent and the reducing agent DTT (Table 1). Protocol D did not show good results in both fresh and dried leaves of apple, as determined by their $\mathrm{A}_{260 / 280}$ absorbance ratios. Figure 2 shows the differences based on agarose gel electrophoresis. The DNA produced by protocols B and C was of very good quality and concentration, and no degradation was observed from either fresh or dried leaves. Protocol B produced the best results for M. sieversii (Figure 2). One of its advantages may be that in the final step, $\mathrm{LiCl}$ is used to remove RNA. Selective precipitation has an advantage over RNAse A treatment because RNA is removed completely rather than being degraded into smaller units (Storts, 1993). However, this protocol is also the most labor intensive of the five, because several solutions need to be prepared, it demands a great deal of time for extraction of the samples, and requires a large quantity of microcentrifuge tubes. 
K. Aubakirova et al.

1284

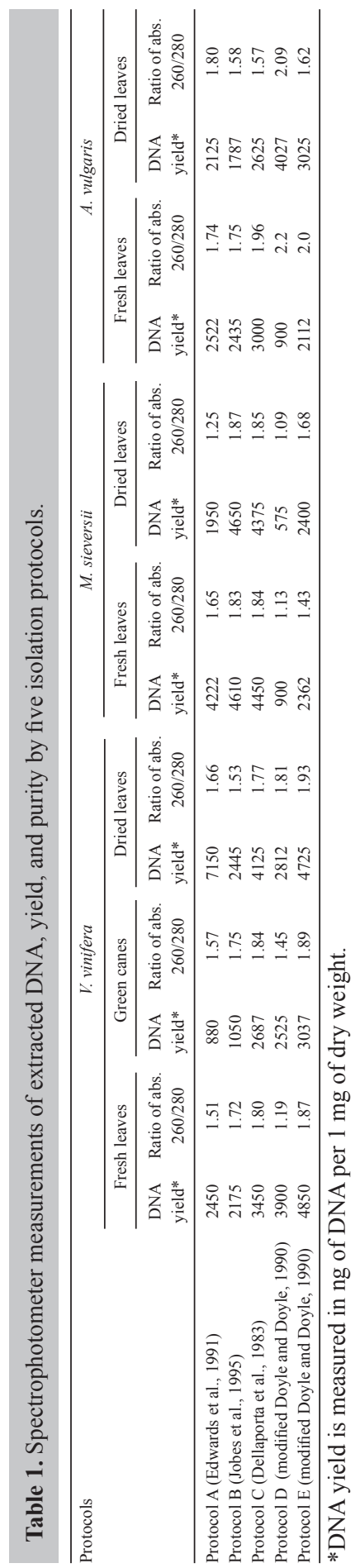




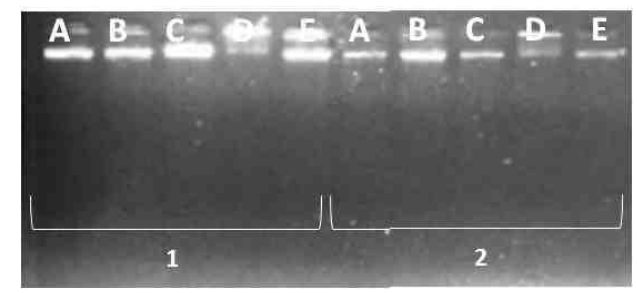

Figure 2. Electrophoretic analysis of total DNA from Malus sieversii extracted by protocols: A. modified Edwards et al. (1991); B. modified Jobes et al. (1995); C. modified Dellaporta et al. (1983); D. modified Doyle and Doyle (1990); E. modified Doyle and Doyle (1990); lane 1 = fresh leaves; lane 2 = dried leaves; lane $M=$ GeneRuler $^{\mathrm{TM}}$ 1-kb DNA Ladder Plus (Fermentas).

In the third group, protocols $\mathrm{A}, \mathrm{B}$, and $\mathrm{C}$ showed good results for fresh leaves of $A$. vulgaris (Table 1). Protocols D and E produced poor results for both fresh and dried leaves, as their $\mathrm{A}_{260 / 280}$ values were higher than 2.0. This might indicate contamination of extracted DNA with RNA and its traces (Figure 3). The $\mathrm{A}_{260 / \mathrm{A} 280}$ ratio of the DNA ranged from 1.7 to 1.9 , indicating that the isolated gDNA was largely free from protein and RNA contamination. The extracted gDNA showed no visible RNA contamination, as determined by agarose gel electrophoresis.

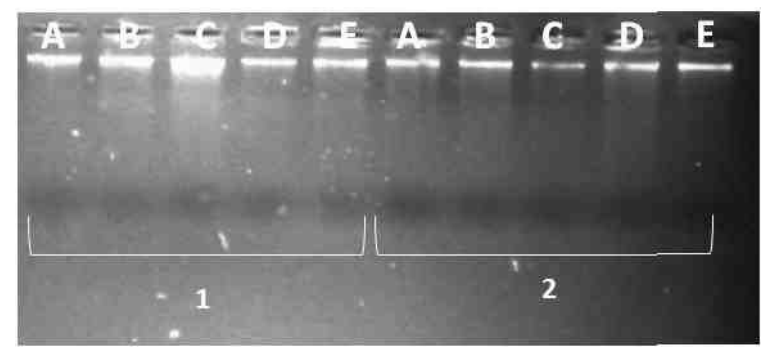

Figure 3. Electrophoretic analysis of total DNA from Armeniaca vulgaris extracted by the protocols: A. modified Edwards et al. (1991); B. modified Jobes et al. (1995); C. modified Dellaporta et al. (1983); D. modified Doyle and Doyle (1990); E. modified Doyle and Doyle (1990); lane 1 = fresh leaves; lane 2 = dried leaves; lane $M=$ GeneRuler $^{\mathrm{TM}} 1-\mathrm{kb}$ DNA Ladder Plus (Fermentas).

To obtain good quality DNA, the utilization of fresh and young leaf tissue is ideal (Sytsma et al., 1993). However, the use of dried leaf material saves time in collecting plant material during extensive field studies. The present study showed that the quality of DNA from dried leaves was mostly good in all protocols tested. However, the result depended on the plant species and the specific desiccation procedure. Therefore, even closely related species might require different isolation protocols (Weishing et al., 1995).

The best DNA quality for all three species was obtained with protocol $\mathrm{C}$, which is a modification of the Dellaporta et al. (1983) method, in which PVP was used to bind phenolic compounds and high molar concentration of potassium acetate was used to inhibit co-precipitation of polysaccharides. DNA extracted by this method showed $\mathrm{A}_{260 / 280} \mathrm{~nm}$ ratios of 1.7-1.9 and successful PCR amplification of the 18S ribosomal DNA gene (Figure 4). 




Figure 4. Amplification of $18 \mathrm{~S}$ ribosomal DNA gene $(870 \mathrm{~kb})$ for 3 groups samples from protocols A-E: 1 st group (lanes 1-15) Vitis vinifera: lanes 1-5 = fresh leaves, lanes 6-10= green canes, lanes 11-15=dried leaves; 2 nd group $($ lanes 16-25) Malus sieversii: lanes 16-20 = fresh leaves, lanes 21-25= dried leaves; 3rd group (lanes 26-35) Armeniaca vulgaris: lanes 26-30 = fresh leaves, lanes 31-35 = dried leaves. Protocol A (modified Edwards et al., 1991): lanes 1, 6, 11, 16, 21, 26, 31; protocol B (modified Jobes et al., 1995): lanes 2, 7, 12, 17, 22, 27, 32; protocol C (modified Dellaporta et al., 1983): lanes 3, 8, 13, 18, 23, 28, 33; protocol D (modified Doyle and Doyle, 1990): lanes 4, 9, 14, 19, 24, 29, 34; protocol E (modified Doyle and Doyle, 1990): lanes 5, 10, 15, 20, 25, 30, 35; lanes $M$ - GeneRuler ${ }^{\mathrm{TM}} 1$-kb DNA Ladder Plus (Fermentas).

\section{ACKNOWLEDGMENTS}

Research supported by grants \#0048/GF and \#0043/GF under The Budget Program "120" "Grant Funding for Research" by the Ministry of Education and Science, Republic of Kazakhstan.

\section{REFERENCES}

Akinnagbe A, Ji XB, Yang M and Ewald D. (2011). Ethanol pretreatment increases DNA yields from dried tree foliage. Conservat. Genet. Resour. 3: 409-411.

Ausubel FM, Brent R, Kingston RE, Moore DD, et al. (2002). Short Protocols in Molecular Biology. 5th edn. John Wiley \& Sons Publications, New York.

Balik J, Kyseláková M, Vrchotová N, Tríska J, et al. (2008). Relations between polyphenols content and antioxidant activity in vine grapes and leaves. Czech J. Food Sci. 26: S25-S32.

Bushra C, Afshan Y, Tayyab H and Riazuddin S (1999). Mini-scale genomic DNA extraction from cotton. Plant Mol. Biol. Rep. 17: 1-7.

Dellaporta SL, Wood J and Hicks JB (1983). A plant DNA mini preparation: Version II. Plant Mol. Bio. Rep. 1: 19-21.

Doyle JJ and Doyle JL (1990). Isolation of plant DNA from fresh tissue. Focus 12: 13-15.

Edwards K, Johnstone C and Thompson C (1991). A simple and rapid method for the preparation of plant genomic DNA for PCR analysis. Nucleic Acids Res. 19: 1349.

Fang G, Hammar S and Grumet R (1992). A quick and inexpensive method for removing polysaccharides from plant genomic DNA. Biotechniques 13: 52-4, 56.

Guillemaut P and Maréchal-Drouard L (1992). Isolation of plant DNA: a fast, inexpensive and reliable method. Plant Mol. Biol. Rep. 10: 60-65.

Halliwell B (1990). How to characterize a biological antioxidant. Free Radic. Res. Commun. 9: 1-32.

IUCN Red List of Threatened Species (2012). Version 3.1. International Union for Conservation of Nature. Avaliable at [http://www.iucnredlist.org/details/63405/0]. Accessed on February, 2013.

Jobes DV, Hurley DL and Thien LB (1995). Plant DNA isolation: a method to efficiently remove polyphenolics, polysaccharides and RNA. Taxon 44: 349-386. 
Kulkarni M, Borse T and Chaphalkar S (2001). Isolation and purification of genomic DNA from black plum (Eugenia jambolana Lam.) for analytical applications. Int. J. Biotechnol. Biochem. 3: 49-55.

Lodhi MA, Ye GN, Weeden NF and Reisch BI (1994). A simple and efficient method for DNA extraction from grapevine cultivars, Vitis species and Ampelopsis. Plant Mol. Biol. Rep. 12: 6-13.

Loomis WD (1974). Overcoming problems of phenolics and quinones in the isolation of plant enzymes and organelles. Methods Enzymol. 31: 528-544.

Samarakoon T, Wang SY and Alford MH (2013). Enhancing PCR amplification of DNA from recalcitrant plant specimens using a trehalose-based additive. Appl. Plant Sci. 1: 1200236.

Storts D (1993). Promega Technical Manual 24 fmol DNA Sequencing System (TM024). Promega Corporation, Madison.

Sytsma K, Givnish TJ, Simt JF and Hahn WJ (1993). Collection and Storage of Land Plant Samples for Macromolecular Comparisons. In: Methods in Enzymology - Molecular Evolution: Producing the Biochemical Data (Zimmer EA, White TJ, Cann RL and Wilson AC, eds.). Academic Press, San Diego, 23-38.

Vavilov NI (1926). Studies on the origin of cultivated plants. Trudy Byuro Prikl Bot. 16: 139-245.

Velasco R, Zharkikh A, Affourtit J, Dhingra A, et al. (2010). The genome of the domesticated apple (Malus x domestica Borkh.). Nat. Genet. 42: 833-839.

Weishing K, Nybom H, Wolff K and Meyer W (1995). DNA Isolation and Purification. In: DNA Fingerprinting in Plants and Fungi. CRC Press, Boca Raton, 44-59. 